\title{
PARTISIPASI WANITA NELAYAN DALAM \\ PENGELOLAAN LINGKUNGAN WILAYAH PESISIR KABUPATEN BANTUL
}

\author{
Rahmat Slamet Suyoto \\ NIDN :0503096701 \\ e-mail :lppmapi@gmail.com \\ Oktiva Anggraini \\ NIDN : 0528106801 \\ e-mail : oktivabiyan28@gmail.com \\ Politekhnik API Yogyakarta
}

\begin{abstract}
Efforts to environmental conservation and management of fisheries products tend to focus on fishing compared with the chain of local values relating to the economy and the labor market. The participation of women fishers more often underappreciated. This study aims to determine the participation of women in the fishing and marine fisheries management in Bantul, with a qualitative approach, method of interview, observation, focus group discussions and documentation. The study took purposively selected locations on the coast and coastal New Depok Parangtritis, Bantul.

The results showed a number of examples of environmental conservation programs fishermen ruled out the role of women in the planning, implementation and evaluation of programs. Women devote more time fishing on their domestic responsibilities, livelihood diversification choice more often limited. This limitation is exacerbated by the lack of education. Becomes important, when the purpose of development in line with environmental management and profitable position of women in environmental management. Because of this, awareness and participation of tourism stakeholders including women fishing is very needed in sustainable environmental management. This participation from the planning, implementation, evaluation of the benefit received by women fishers. Participation which originally symbolic of the study sites can be developed with intensive mentoring extension of the activities of women's groups of fishermen manifest into independent participation. Collective action fisher woman other than as a means of gathering, enriching also useful as an alternative source of business capital. Through the activities of formal, informal them, toma and extension convey the importance of preserving the environment. Efforts to add events, travel and travel product diversification initiated by the government and the private sector are expected to increase the participation of women fishing and sustainable environmental management.
\end{abstract}

Keywords: women fishing, environment, participation.

\section{PENDAHULUAN}

Kepariwisataan yang bertumpu pada keunikan, kekhasan, kelokalan dan keaslian akan menempatkan keanekaragaman, yang pada gilirannya pengembangannya

1 Dosen Politeknik API Yogyakarta
2 Dosen Univ. Widya Mataram Yogyakarta mampu untuk menunjang kelestarian dan memperkukuh jati diri bangsa serta lingkungan alam. Kegiatan kepariwisataan Indonesia pun demikian, mempunyai akar yang kuat dalam masyarakat yang besumber pada nilai-nilai 
agama dan budaya yang dianut bangsa Indonesia.

Sebagai aktualisasi sistem ekonomi kerakyatan, masyarakatlah pelaku aktif pengembangan pariwisata yang muaranya akan meningkatkan kesejahteraan masyarakat itu sendiri. Penelitian Agustina (2012) menunjukkan partisipasi masyarakat yang cukup tinggi, menjadikan Desa Budaya Kertalangu, Bali yang diresmikan pada 22 Juni 2007, mampu mendorong desa tersebut sebagai konservasi pertanian tradisional, edukasi pertanian dan menjaga eksistensi budaya Bali di tengah era modernisasi. Sementara itu, kajian Pamulardi (2006), menunjukkan pelibatan masyarakat desa Tingkir Salatiga dalam agrowisata, dapat mendatangkan keuntungan ekonomi tanpa mengubah mata pencaharian tetap mereka sebagai petani.

Sepertinya halnya tahapan pembangunan di berbagai kawasan, tumbuh dan berkembangnya suatu destinasi wisata, melibatkan anggota masyarakat dengan segala perangkat yang dimilikinya (Fandeli, 2005; Muljadi, 2009). Demikian halnya dengan pembangunan wisata di kawasan pesisir, sebagai komponen penting dari masyarakat pesisir, wanita nelayan layak diperhitungkan karena posisinya yang strategis (Weeratunge et al., 2010, Arenas and Lentisco, 2011). Dalam kegiatan berbasis perikanan dan kelautan, wanita nelayan berperan sebagai pedagang pengecer, pengumpul ikan, pedagang besar, buruh upahan, maupun tenaga pengolah hasil perikanan. Namun demikian, dalam berbagai aspek kajian ataupun programprogram pembangunan pesisir mereka tidak banyak tersentuh (Anggraini, 2011, Anggraini, 2012). Di beberapa wilayah bahkan peranan wanita nelayan, juga sering merambah wilayah yang dianggap sebagai dunia kerja kaum laki-laki yaitu penangkapan ikan seperti yang banyak ditemukan dalam kegiatan penangkapan kepiting di daerah mangrove Teluk Bintuni Papua. Peran produktif ini, bagi wanita nelayan bahkan sering mengalahkan peran reproduktif atau domestiknya. Hasil kajian kajian Momsen (2004) menunjukkan ketika mereka melakukan aktivitas produktif di pesisir, peran tersebut ditinggalkan sementara dan diserahkan kepada kepada anak atau ibu/nenek mereka. Sungguhpun demikian, kontribusi wanita nelayan sering tidak diperhitungkan dalam sensus pemerintah. Dalam pengembangan wisata bahari pun, peran wanita nelayan beragam mulai dari pelayanan jasa wisata hingga wisata kuliner (Anggraini, 2011).

Dengan berlabel kekhasan tersebut, Pantai Baru Bantul, yang terletak $32 \mathrm{~km}$ dari Yogyakarta merupakan salah satu destinasi wisata baru yang telah mendapat perhatian untuk dikembangkan menjadi wisata kuliner. Sejak dibukanya pantai Baru Bantul yang berdekatan dengan Tempat Pelelangan Ikan (TPI) Pandan Simo tahun 2010, kawasan ini berbenah diri yang pada gilirannya diharapkan dapat menyusul ketenaran lokasi kuliner lain seperti pantai Depok dan pantai Parangtritis. Ketertinggalan pantai Baru-Baru ini disebabkan sejumlah faktor seperti promosi media yang kurang, pola kerjasama stakeholder pariwisata belum mendukung dan sarana prasarana terbatas serta pelayanan dan sanitasi kuliner kurang memuaskan pembeli. Ketersediaan kedai ikan dan pusat penjualan makanan tersebut tidak lepas dari berbagai masalah seperti kurangnya kebersihan, menu yang ditawarkan dan pemasarannya.

Pre-survey peneliti menunjuk-kan, di kawasan pantai Baru Bantul terdapat 11 (sebelas) kelompok pengolah ikan dan pengusaha kuliner yang masing-masing 
kelompok beranggotakan 3-5 orang wanita nelayan. Sebagai usaha kecil menengah, pada umumnya mereka masih kesulitan dalam permodalan, manajemen keuangan dan melakukan diversifikasi usaha. Ketiadaan makanan khas atau souvenir yang dikembangkan dari potensi lokal juga menjadi tantangan tersendiri dalam mewujudkan kegiatan ekonomi kreatif masyarakat sekitar. Di lain sisi, sejak dikembangkan tahun 2010, pantai Baru yang ingin menonjolkan keindahan hamparan cemara di sepanjang pantai menghadapi berbagai persoalan lingkungan yang menuntut partisipasi yang tinggi dari masyarakatnya.

Berangkat dari latar belakang masalah tersebut, menarik kiranya dikaji melalui penelitian ini:

1. Bagaimana partisipasi wanita nelayan dalam pengelolaan lingkungan di kawasan pesisir Kabupaten Bantul?

2. Bentuk-bentuk partisipasi apa saja yang dilakukan wanita nelayan untuk menunjang pengelolaan lingkungan yang berkelanjutan?

3. Kendala apa yang ditemui wanita nelayan dalam menyalur-kan partisipasinya?

Penelitian ini secara khusus dirancang untuk :

1. Untuk menganalisa kontribusi partisipasi wanita nelayan dalam pengelolaan lingkungan di kawasan pesisir Kabupaten Bantul.

2. Untuk mengetahui bentuk-bentuk partisipasi wanita nelayan dalam pengelolaan lingkungan di kawasan pesisir Kabupaten Bantul.

3. Untuk mengkaji kendala yang ditemui wanita nelayan dalam menyalurkan partisipasinya.
Hasil riset ini akan bermanfaat untuk pengelolaan wilayah pesisir berkelanjutan yang titik tekannya pada pemetaan partisipasi wanita nelayan dalam perencanaan, pelaksanaan, pengawasan dan pengembangan kegiatan ekonomi pesisir. Manfaat penelitian ini diharapkan menjadi masukan bagi pemerintah Kabupaten Bantul dan masyarakat dalam pengelolaan lingkungan pesisir di kawasan pesisir Kabupaten Bantul. Dengan demikian pengalokasian sumber daya alam dan lingkungan dapat dilakukan secara proporsional, optimal dan berkelanjutan.

\section{LITERATURE REVIEW Partisipasi}

Berbagai ahli mendefinisikan partisipasi dari berbagai segi dan aspek. Paul (1987) mendefinisikan partisipasi sebagai suatu proses aktif dari kelompok penerima manfaat dalam mempengaruhi arah dan pelaksanaan proyek pembangunan dengan maksud untuk meningkatkan kesejahteraan mereka, baik dalam hal pendapatan, pertumbuhan ekonomi pribadi, kepercayaan diri atau nilai-nilai lain yang mereka junjung tinggi.

Hampir senada, Bryant dan White (1989) mendefinisikan partisipasi sebagai pelibatan diri masyarakat dalam penyusunan rencana dan pelaksanaan proyek. Keterlibatan yang dimaksudkan adalah keterlibatan secara aktif oleh masyarakat setempat sejak mulai perencanaan, pelaksanaan, dan pengawasan terhadap kegiatan pembangunan (Nuryanto, 2007). Sedangkan Mardikanto (2007) berkonsepsi bahwa partisipasi adalah suatu bentuk keterlibatan dan keikutsertaan secara aktif dan sukarela baik karena alasan-alasan dari dalam (intrinsik) maupun dari luar (ekstrinsik) dalam keseluruhan proses kegiatan yang mencakup: 
pengambilan keputusan dalam perencanaan, pelaksanaan, pengendalian (pemantauan, evaluasi dan pengawasan serta pemanfaatan hasil kegiatan yang dicapai.

Berdasarkan pendapat beberapa ahli tersebut, partisipasi masyarakat menjadi elemen krusial dalam pembangunan nasional. Tidak hanya pembangunan dengan paradigma top-down, terlebih paradigma pembangunan bottom-up sangat membutuhkan partisipasi masyarakat dalam menjalankan roda pembangunan. Posisi yang penting dan strategis dalam pembangunan terutama dalam perencanaan pembangunan membuat partisipasi masyarakat dapat dilihat dalam tiga hal. Pertama, partisipasi masyarakat merupakan suatu alat guna memperoleh informasi mengenai kondisi, kebutuhan masyarakat setempat, yang tanpa kehadirannya program pembangunan serta proyek-proyek akan gagal. Kedua, bahwa masyarakat akan lebih mempercayai proyek atau program pembangunan jika merasa dilibatkan dalam proses persiapan dan perencanaannya karena mereka akan lebih mengetahui seluk beluk proyek tersebut dan akan mempunyai rasa memiliki terhadap proyek tersebut. Ketiga, bahwa merupakan suatu hak demokrasi bila masyarakat dilibatkan dalam pembangunan masyarakat mereka sendiri (Soetrisno, 1995).

Lebih lanjut Sentosa (Atmanto, 1995), mengemukakan 5 unsur penting dalam partisipasi masyarakat yaitu: 1) Komunitas yang menumbuhkan pengertian yang efektif; 2) Perubahan sikap, pendapat dan tingkah laku yang diakibatkan oleh pengertian yang menumbuhkan kesadaran; 3) Kesadaran yang didasarkan atas perhitungan dan pertimbangan; 4) Antusiasme atau spontanitas, yaitu kesediaan melakukan sesuatu yang tumbuh dari dalam lubuk hati sendiri tanpa dipaksa orang lain, dan 5) Adanya rasa tanggungjawab terhadap kepentingan bersama.

\section{Wujud Partisipasi}

Partisipasi masyarakat pada pelaksanaan program pembangunan pada prakteknya beraneka macam wujud yang oleh Hamidjoyo (1991) diklasifikasikan dalam lima bentuk partisipasi yaitu meliputi: 1). Partisipasi ide/gagasan; 2) Partisipasi keterampilan; 3) Partisipasi tenaga; 4) Partisipasi harta benda; 5) Partisipasi uang.

Lain halnya dengan yang dikembangkan oleh Vaneklasen dan Miller (2009) wujud-wujud partisipasi di bagi ke dalam tujuh wujud yaitu:

1. Partisipasi simbolis yaitu masyarakat duduk dalam lembaga resmi tanpa melalui proses pemilihan dan tidak mempunyai kekuasaan yang sesungguhnya.

2. Partisipasi pasif yaitu masyarakat diberi informasi apa yang sudah diputuskan dan apa yang sudah terjadi. Pengambil keputusan menyampaikan informasi tetapi tidak mendengarkan tanggapan dari masyarakat sehingga informasi hanya berjalan satu arah yaitu dari pengambil keputusan ke masyarakat.

3. Partisipasi konsultatif yaitu masyarakat berpartisipasi dengan cara menjawab beberapa pertanyaan. Hasil jawaban masyarakat ini akan dianalisis oleh pihak luar untuk mengidentifikasi masalah dan cara untuk mengatasi masalah tersebut tanpa perlu masukan pandangan masyarakat.

4. Partisipasi dengan insentif material yaitu masyarakat menyumbangkan tenaganya untuk mendapat makanan, 
uang dan imbalan lainnya. Masyarakat menyediakan sumber daya, namun tidak terlibat di dalam memutuskan apa yang dilakukan sehingga mereka tidak memiliki keterikatan untuk meneruskan partisipasinya ketika masa pemberian insentifnya selesai.

5. Partisipasi fungsional yaitu masyarakat berpartisipasi karena ada permintaan dari lembaga eksternal untuk memenuhi tujuan.

6. Partisipasi interaktif yaitu masyarakat berpartisipasi dalam mengembangkan dan meng-analisa rencana kerja. Partisipasi dilihat sebagai hak, bukan hanya sebagai alat untuk mencapai tujuan, prosesnya melibatkan metodologi dalam mencari perspektif yang berbeda serta menggunakan proses belajar yang terstruktur. Mengingat masyarakat dilibatkan dalam pengambilan keputusan maka mereka mempunyai keterikatan untuk mempertahankan tujuan dan institusi lokal yang ada di masyarakat menjadi kuat.

7. Pengorganisasian diri yaitu masyarakat berpartisipasi dengan merencanakan secara mandiri. Mereka mengembangkan kontak dengan lembaga eksternal untuk sumber daya dan saran-saran teknis yang dibutuhkan, namun kontrol terhadap sumber daya tersebut digunakan berada di tangan masyarakat sepenuhnya. Tipe partisipasi masyarakat ini sangat ideal, karena menunjukkan bagaimana masyarakat sudah sangat berdaya, mampu mengadvokasi dirinya sendiri masalah yang menimpanya.

\section{Peran Wanita Nelayan}

Wanita nelayan adalah perempuan yang bergerak di bidang perikanan sebagai bakul ikan, pengelola hasil perikanan atau pengumpul biota laut yang suami atau bapaknya berprofesi sebagai nelayan (DKP, 2001). Menurut Sharma (2003) peran perempuan di bidang perikanan di Asia ada empat yaitu: 1). Sebagai pekerja di bidang perikanan (dibayar atau tidak dibayar; 2). sebagai pekerja di pemrosesan ikan penuh atau paruh waktu); 3). orang yang bertanggung jawab terhadap kelompok atau komunitas dan 4). sebagai pekerja di luar bidang perikanan (seperti pedagang warung). Pekerjaan yang dilakukan perempuan ini jarang dianggap sebagai pekerjaan produktif umumnya sebagai perpanjangan dari pekerjaan domestik. Nilai sosial rendah dilekatkan kepada pekerjaan domestik dan komunitas yang dilakukan perempuan.

Secara spesifik, Iksan (2003) mengamati kegiatan wanita nelayan di Pulau Jawa, yang pada akhirnya terdapat klasifikasi berikut:

1. Peran sebagai istri yang mengurus anak dan suami, termasuk membantu membersih-kan jaring, menyulam jaring, mengelola hasil tangkapan agar siap dipasarkan sampai dengan menjual hasil tangkapan ikan oleh suami.

2. Sebagai pekerja hasil laut rumahan (seperti: fillet atau pemotong ikan, picker atau pengupas kulit rajungan, kerang, keong dan udang, perebus kerang atau keong).

3. Sebagai pekerja pabrik perikanan (seperti: fillet, pembekuan ikan atau udang, pengepak dan pemberi label).

4. Menjadi bakul yang memasok hasil tangkapan nelayan atau panen ikan kepada para supplier atau pabrik. 
5. Menjadi bendahara (pemegang keuangan) dari perusahaan keluarga (supplier).

6. Menjadi Supplier yang memasok bahan baku ke pabrik.

7. Menjadi Quality Control pabrik.

8. Menjadi eksportir perikanan ke mancanegara.

Dalam hal partisipasi, partisipasi wanita nelayan dalam hal pengambilan keputusan menurut Kumar (2004) pada umumnya tidak terorganisir dengan baik dan kurang efektif sebagai kekuatan politik dibanding lelaki. Ketika perempuan diberi tempat dalam suatu organisasi atau proses pengambilan keputusan maka hakekatnya mereka akan membawa suatu prespektif yang meletakkan peningkatan kualitas hidup dan mata pencaharian berbasis perikanan sebagai hal yang mendasar.

\section{Pengelolaan Wilayah Pesisir Berkelanjutan}

\section{Dimensi ekologis}

Pemanfaatan sumberdaya pesisir secara berkelanjutan berarti sebagai upaya mengelola segenap kegiatan pembangunan yang terdapat di suatu wilayah yang berhubungan dengan wilayah pesisir agar total dampaknya tidak melebihi total kapasitas fungsionalnya. Setiap ekosistem alamiah memiliki empat fungsi pokok bagi kehidupan manusia, yaitu:

- Sebagai jasa-jasa pendukung kehidupan, mencakup berbagai hal yang diperlukan bagi eksistensi kehidupan manusia seperti udara dan air bersih serta ruang bagi segenap kegiatan manusia.

- Penyedia jasa-jasa kenyamanan, berupa suatu lokasi beserta atributnya yang indah dan menyejukkan yang dapat dijadikan tempat berekreasi serta pemulihan kedamaian jiwa.
- Penyedia sumberdaya alam, baik yang dapat dikonsumsi langsung maupun sebagai masukan dalam proses produksi.

- Penerima limbah, utamanya dari kegiatan manusia hingga terdapat suatu kondisi yang aman dan bersih.

Berdasarkan keempat fungsi ekosistem di atas maka secara ekologis terdapat tiga persyaratan yang dapat menjamin tercapainya pembangunan berkelanjutan, yaitu: (1) keharmonisan spasial, (2) kapasitas asimilasi, dan (3) pemanfaatan berkelanjutan.

\section{Dimensi sosial ekonomi}

Mensyaratkan bahwa manfaat atau keuntungan yang diperoleh dari kegiatan penggunaan suatu wilayah pesisir serta sumberdaya alamnya harus diprioritaskan untuk me-ningkatkan kesejahteraan penduduk terutama mereka yang ekonomi lemah guna menjamin kelangsungan pertumbuhan ekonomi wilayah.

\section{Dimensi sosial politik}

Pada umumnya permasalahan lingkungan hidup bersifat eks-ternalitas, artinya pihak yang menderita (mengalami kerugian) akibat pencemaran dan atau kerusakan lingkungan bukanlah pembuat kebijakan melainkan pihak lain serta permasalahan tersebut biasanya muncul setelah beberapa waktu, tidak langsung pada waktu itu. Mengingat karakteristik permasalahan tersebut maka pembangunan berkelanjutan hanya dapat dilaksanakan dalam sistem dan suasana politik yang demokratis dan transparan yang didukung oleh political will pemerintah.

\section{METODE PENELITIAN Definisi Konsep}

Partisipasi wanita nelayan dalam pengelolaan lingkungan wilayah pesisir 
adalah peran serta atau keterlibatan wanita nelayan pada tahap perencanaan, pelaksanaan, pemantauan dan evaluasi serta pemanfaatan hasil baik dalam wujud ide, tenaga dan materi dalam mendayagunakan sumber daya pesisir dan laut secara optimal dan berkelanjutan dengan kaidah kelestarian lingkungan.

\section{Definisi Operasional}

Untuk mengetahui tingkat partisipasi wanita nelayan dalam pengelolaan lingkungan wilayah pesisir, indikatorindikatornya sebagai berikut:

a. Meningkatnya kesadaran wanita nelayan akan pentingnya kelestarian lingkungan.

b. Keterlibatan wanita nelayan dalam perencanaan pengelolaan lingkungan.

c. Keterlibatan wanita nelayan dalam pelaksanaan pengelolaan lingkungan.

d. Keterlibatan wanita nelayan dalam evaluasi pengelolaan lingkungan.

e. Berkembangnya aksi kolektif wanita nelayan dalam pengelolaan lingkungan.

\section{Jenis Penelitian}

Jenis penelitian yang digunakan adalah deskriptif kualitatif dengan tujuan untuk mengeksplorasi dan mengklasifikasi gambaran suatu gejala dan kenyataan sosial dengan jalan mendiskripsikan variabel sesuai dengan masalah inti (Nawawi, 2001). Dalam penelitian ini, peneliti akan mendeskripsikan secara sistematis, faktual dan akurat mengenai kontribusi partisipasi wanita nelayan dalam pengelolaan lingkungan di wilayah pesisir Kabupaten Bantul beserta kendala partisipasi.

Lokasi penelitian ditentukan secara purposive, yakni di desa pesisir Poncosari, pantai Baru dan desa pesisir Parangtritis Kabupaten Bantul. Dipilihnya daerah tersebut dengan pertimbangan bahwa wisata kuliner saat ini tengah dikembangkan di kecamatan tersebut, di samping perikanan tangkap. Dibanding TPI di wilayah pesisir lainnya di Kabupaten Bantul, desa-desa pantai ini banyak dikunjungi wisatawan karena keindahan panorama dan sajian wisata kulinernya. Wisata kuliner tersebut menjadi alternatif pilihan bagi turis asing maupun domestik. Sebagai destinasi wisata yang tengah dikembangkan, wilayah pesisir tak luput dari persoalan lingkungan. Sebagian lahan pesisir Desa Parangtritis berupa gumuk pasir (sand dune) yang dilindungi dan tidak diijinkan untuk dikembangkan menjadi daerah pertanian. Lahan pesisir ini dibiarkan ditumbuhi rumput dan tanaman pasir secara alami. Di sisi lain, kelompok sadar wisata dan kelompok nelayan serta wanita nelayannya, sebagaimana yang diharapkan pemda setempat, berupaya agar dalam mengelola potensi laut tetap menjaga keseimbangan ekosistem.

\section{Sumber Data}

\section{a. Sumber Data Primer \\ Merupakan data yang diperoleh} langsung dari informan. Penentuan key informan dilakukan dengan purposive sampling yakni dengan memperhatikan kemampuan maupun pengetahuan narasumber dengan topik yang dikaji. Dalam hal ini adalah pemrakrasa pengelolaan lingkungan yakni Dinas Pariwisata Kabupaten Bantul, Dinas Kelautan dan Perikanan Kabupaten Bantul, organisasi terkait dan kelompok sasaran yakni pemuka atau tokoh masyarakat dan kelompok wanita nelayan.

b. Sumber Data Sekunder

Sumber dari dokumen yang berujud buku, jurnal, surat kabar, gambar dan sebagainya. 
Teknik Pengumpulan Data \& Teknik Analisa Data

Dalam penelitian kualitatif, teknik pengumpulan data yang proses pengumpulan datanya menggunakan teknik yang saling berkaitan dan melengkapi, yaitu:

a. In-depth Interview,

Teknik wawancara mendalam akan dilakukan baik terhadap informan. Hasil wawancara akan direkam dengan menggunakan alat rekam walkman (tape recorder).

b. Observasi

Teknik observasi dilakukan terhadap fenomena yang terjadi di komunitas wanita nelayan, difokuskan pada karakteristik wanita nelayan, peran serta mereka dalam penataan lingkungan. Di samping itu, untuk melengkapi data dokumentasi, peneliti mengamati potensi wilayah dan isu lingkungan di lokasi penelitian.

c. Dokumentasi

Melalui teknik dokumentasi diharapkan dapat dipelajari alternatif teoritis dan fakta-fakta empirik barn mengenai hubungan partisipasi wanita nelayan dengan penataan lingkungan di wilayah pesisir Kabupaten Bantul. Dengan teknik ini pula akan dapat ditelusuri dokumendokumen tertulis, terbitan-terbitan khusus maupun selebaran-selebaran yang dianggap memiliki signifikansi yang kuat dengan penelitian.

Dengan menggunakan metode deskriptif maka tahapan-tahapan penelitian ini sebagai berikut:

1. Reduksi data, yaitu data yang berhasil dikumpulkan dirangkum dan disederhanakan sehingga ditemukan tema-tema dan pokok-pokok yang dianggap relevan dengan masalah dan tujuan penelitian. Dengan cara ini susunan data akan sistematis dan mudah diatur serta dapat dengan jelas memberikan gambaran mengenai hasil yang dicapai.

2. Penyajian data, yaitu proses menampilkan sekumpulan informasi yang telah disusun dan memberi suatu kesimpulan dalam bentuk tabel, grafik, teks atau bagan.

3. Penarikan kesimpulan, yaitu suatu proses usaha pemahaman terhadap temuan-temuan yang berbentuk catatan tentang keteraturanketeraturan, pola-pola, penjelasan, konfigurasi dan alur sebab akibat proposisi. Dalam penelitian kualitatif, peneliti berusaha menarik kesimpulan yang dilakukan sejak dimulainya proses kontak dengan unit analisis dan selama itu pula berlangsung proses kegiatan verifikasi (Sutopo, 1988:25).

Untuk keabsahan data dalam penelitian ini digunakan metode triangulasi data, yakni teknik pemeriksaan keabsahan data dengan memanfaatkan sesuatu yang lain di luar data itu untuk keperluan pengecekan atau sebagai pembanding terhadap data itu. (Moleong, 2005: 330). Pengujian dilakukan dengan melakukan cross check terhadap beberapa informasi tertentu dengan pihak lain yang memahami atau menguasai permasalahan.

\section{HASIL PENELITIAN}

Keterlibatan Wanita Nelayan dalam Perencanaan Pengelolaan Lingkungan

Keterlibatan wanita nelayan dalam perencanaan pengelolaan lingkungan dapat dilihat dari peran serta, curahan ide wanita 
nelayan pada perencanaan program pengelolaan lingkungan dan pariwisata. Hasil penelitian di dua lokasi menunjukkan bahwa pada umumnya wanita nelayan kurang banyak dilibatkan dalam perencanaan program pengelolaan lingkungan. Hal ini disebabkan keterbatasan pendanaan dan keterbatasan akses wanita nelayan mengakibatkan wanita nelayan lebih banyak menyampaikan aspirasinya melalui perwakilan kelompok. Dalam berbagai program-program pemerintah, perguruan tinggi, CSR swasta, suara wanita nelayan jarang didengar langsung oleh pembuat kebijakan.

Berdasarkan penelusuran di lapangan, minimnya kontribusi partisipasi wanita nelayan ditinjau dari sisi perencanaan disebabkan sistem yang masih meminggirkan suara perempuan, keterbatasan wanita nelayan karena minimnya ketrampilan dan pengetahuan serta kesempatan yang sama dalam mendiskusikan persoalan-persoalan lingkungan.

Dari FGD yang digelar peneliti, terungkap juga fakta, sekalipun dari sisi perencanaan kontribusi wanita nelayan terbatas, para pengurusnya berusaha didengar aspirasinya melalui kegiatankegiatan yang melibatkan mereka. Dialog yang dibangun, meski sederhana, muaranya agar peran wanita nelayan dalam pelestarian lingkungan lebih banyak diperhatikan oleh berbagai pihak. Hal ini berangkat dari pertimbangan bahwa warga akan lebih mempercayai proyek atau program pembangunan jika merasa dilibatkan dalam proses persiapan dan perencanaannya karena mereka akan lebih mengetahui seluk beluk proyek tersebut dan akan mempunyai rasa memiliki terhadap proyek tersebut.

\section{Keterlibatan Wanita Nelayan dalam Pelaksanaan Pengelolaan Lingkungan}

Keterlibatan wanita nelayan dalam pelaksanaan pengelolaan lingkungan dapat dilihat dari kontribusi tenaga, pikiran, waktu bahkan material yang disumbangkan wanita nelayan terhadap pengelolaan lingkungan pesisir. Sekalipun dari sisi perencanaan pengelolaan lingkungan pesisir, wanita nelayan kurang dilibatkan bukan berarti bahwa mereka sulit digerakkan untuk mensukseskan berbagai program pengelolaan lingkungan. Dibanding dengan kelompok wanita nelayan pantai Baru Poncosari, kelompok wanita nelayan pantai Depok lebih giat dalam pelaksanaan pengelolaan lingkungan dan pariwisata. Kontribusi tersebut berwujud materi, sumbangan tempat, waktu, tenaga dan sumbangan berupa uang iuran.

Keterpaduan masyarakat lokal dan pemerintah setempat, tengah dan selalu dilakukan agar tercipta pengelolaan lingkungan yang lebih baik. Dampaknya pun cukup positif pada anggota kelompok formal dan informal di wilayah tersebut, masyarakat lokal tak lagi menjadi obyek pelaksana atau proyek-proyek penataan wisata dari pemerintah. Akan tetapi bermodal partisipasi yang cukup baik dari masyarakatnya, penataan wisata pantai Depok lambat laun menjadi lebih baik.

Berbeda dengan kondisi pantai Depok, Parangtritis, Pantai Baru Pandansimo sejak dibuka tahun 2010 sampai saat ini sudah ada 82 wanung. Awalnya, menurut Ketua Kelompok Kegiatan Pantai Baru, H. Jumali, tidak mudah untuk mengembangkan Pantai Baru dengan melihat para pelaku usaha yang sebelumnya bekerja sebagai petani atau peternak sehingga belum memiliki dasar 
kewirausahaan. Konsep penataan Pantai Baru, mensinergikan beberapa potensi yang ada, seperti pembangkit listrik tenaga hibrid sebagai wisata pendidikan, biogas, kuliner, dan pantai. Untuk itu kerjasama kemitraan dengan berbagai pihak, seperti UGM, sangat dibutuhkan untuk memajukan Pantai Baru. Yang masih oleh Pokgiat dusun pantai Baru adalah cara mengembangkan agrowisata di sisi utara pantai (wawancara dengan Bapak Jumali, September 2013).

Data-data sekunder juga menunjukkan bahwa kegiatan pendampingan telah dirintis sejak tahun 2011 di pantai Baru. Kelompok pelaku usaha perempuan menjadi sasaran kegiatan agar mereka menjadi lebih mandiri. Berbagai pelatihan seperti manajemen keuangan, kelembagaan hingga pengemasan olahan kuliner telah disiapkan. Prinsipnya adalah penguatan baik di bidang informasi, data maupun SDM. Selain penguatan kelompok usaha perempuan di Pantai Baru, UGM terjun melalui mahasiswa KKN serta pengelolaan kawasan tangguh bencana. UGM dengan KKN maupun program tanggap bencana dan DERU (Disaster Response Unit) siap mendukung program-program penguatan tersebut.

Kegiatan pengelolaan lingkungan dan pengembangan pariwisata pesisir di dua lokasi penelitian banyak yang dikaitkan dengan kegiatan ekonomi budaya yang melibatkan partisipasi wanita nelayan. Kegiatan-kegiatan upacara adat yang unik dilakukan di wilayah penelitian meliputi Upacara adat Desa, Bekti Pertiwi, dan Upacara Labuhan Kraton Yogyakarta. Upacara Adat desa pada umumnya bersih desa/sedekah bumi, nyadran. Upacara ini diselenggarakan setahun sekali pada bulanbulan Jawa (Sapar, Sura) atau sebelum panen (Ruwah), misalnya upacara bersih desa diselenggarakan pada bulan Sapar sesudah selesai panen. Sedangkan upacara adat Labuhan Kraton Yogyakarta merupakan upacara adat yang dilakukan oleh Kraton Yogyakarta. Penyelenggaraan labuhan dilaksanakan pada waktu Sri Sultan Hamengku Buwono IX yang dapat dikatakan berbeda dengan penyelenggarakan labuhan sebelum-nya. Pada masa pemerintahan Sri Sultan Hamengku Buwono I, upacara labuhan diadakan apabila terjadi penobatan seorang raja, dimana pelaksanaannya satu hari sesudah penobatan berlangsung (jumenengan). Di samping ketiga labuhan tersebut, ada lagi peristiwa labuhan yang diadakan untuk kepentingan khusus, dimana waktu pelaksanaannya tidak tentu dan disesuaikan dengan kebutuhan yang dilaksanakan hanya di Parangkusumo. Salah satu labuhan untuk kepentingan khusus adalah labuhan yang diadakan pada saat Sri Sultan berkenan akan menikahkan putera/puterinya.

Pelaksanaan labuhan khusus berbeda dengan labuhan rutin. Labuhan khusus diselenggarakan sangat sederhana dan tidak banyak diikuti dan disaksikan oleh masyarakat umum. Kegiatan kesenian yang melibatkan wanita nelayan diselenggarakan di wilayah penelitian berupa seni tari (reog, jathilan, tari-tari dan wayang orang), seni theater (ketoprak dan srandul), seni musik (karawitan, slawatan, gejok lesung, mocopat, terbanan, thek-thek).

\section{Aksi Kolektif Wanita Nelayan}

Wujud lain dari partisipasi wanita nelayan selain partisipasi dibidang perencanaan hingga evaluasi adalah terbangunnya aksi kolektif wanita nelayan terhadap pengelolaan lingkungan dan pariwisata. Aksi kolektif ini dapat dilihat dari kian lembaganya nilai-nilai, norma 
hingga aksi pengumpulan materi yang disisihkan wanita nelayan untuk kegiatan lingkungan. Pemberdayaan melalui pengembangan aksi kolektif sama artinya dengan pengembangan koperasi atau kelompok usaha bersama. Aksi kolektif membuka kesempatan bagi masyarakat untuk membentuk kelompok-kelompok yang diinginkan, tidak terbatas pada koperasi akan tetapi muaranya tetap untuk kesejahteraan anggota secara individu.

Berdasarkan data empiris dan data sekunder yang peneliti kumpulkan di dua lokasi penelitian, nampak perbedaan yang cukup mencolok meskipun ada pula persamaan di pihak yang lain. Di pantai Depok, aksi kolektif wanita nelayan lebih digerakkan oleh kekuatan pemimpin desa dan pengurus koperasi yang dominan. Semula partisipasi wanita nelayan bersifat simbolis, namun pada gilirannya setelah wanita nelayan merasakan manfaat dari yang mereka sumbangkan: retribusi, bagi hasil KUB dan penjualan jasa wisata, mereka tergerak untuk meningkatkan partisipasinya.

Keberadaan koperasi Wisata Mina Bahari 45 Pantai Depok cukup dirasakan manfaatnya oleh wanita nelayan, terutama dalam mengatasi masa paceklik. Koperasi dapat memberikan pinjaman reguler maupun dengan cara sebrak. Dengan kemudahan ini, wanita nelayan tidak berkeberatan bila sebagian pendapatannya disisihkan untuk dana sosial. Bantuan koperasi sebagai dana sosial pada SD dan pengembangan PAUD cukup berarti bagi wanita nelayan karena putra-putri mereka lebih terfasilitasi pendidikannya. Keberadaan fasilitas pendidikan di daerah pesisir minim sarana prasarana dari pemerintah sehingga bantuan tersebut besar artinya untuk pengembangan dan proses belajar siswa didik.
Even-even kemasyarakatan yang banyak digelar di pantai Depok selama ini, seperti Upacara Labuhan, Pesta Rakyat saat Idul Fitri, Hari Bahari, juga menggunakan dana tersebut sehingga memudahkan pengumpulan dana sekaligus pertanggungjawabannya pada masyarakat. Keberhasilan ini tak lepas dari peran kepemimpinan dan bertahannya normanorma sosial yang ada. Dinamika usaha wanita nelayan memang tidak luput dari konflik pula, akan tetapi hal itu dapat diatasi dengan kepemimpinan yang kuat dari ketua kelompok wanita nelayan yang bekerjasama dengan tokoh masyarakat setempat (wawancara dengan manager Koperasi, Aisya, November 2013).

Terdapat sanksi bagi mereka yang melanggar aturan yang telah disepakati warga baik itu sanksi sosial maupun sanksi ekonomi. Ketegasan ini diperlukan agar tatanan masyarakat yang lama terbangun tidak dirusak oleh sekelompok orang yang berperilaku oportunis, seenaknya yang merusak nilai-nilai yang telah disepakati (wawancara dengan ketua kelompok wanita nelayan, Ibu Nunik, Agustus 2013).

Sebaliknya aksi kolektif yang dikembangkan di pantai Baru masih prematur dan memerlukan kajian untuk mencari bentuk yang benar-benar berguna bagi masyarakat. Beberapa aksi kolektif yang berkembang seperti Program Zero Waste maupun pengelolaan lingkungan oleh pemda setempat, bukan murni ide gagasan masyarakat. Namun akhirnya karena aksi semi kolektif ini menguntungkan masyarakat, terutama wanita nelayan tergerak untuk serius memikirkan masalah lingkungan. Dengan menjaga kebersihan lingkungan, penguntung atau wisatawan akan lebih merasa betah. Kegiatan bersih kawasan pesisir setiap bulan yang diprakarsai 
Pokgiat (Kelompok Kegiatan) Poncosari menuai partisipasi antusias wanita nelayan. Kamar mandi, masjid, sapras pendopo dan tempat parkir menjadi target yang harus dibersihkan selain warung milik mereka sendiri.

Melalui pokgiat pula, dana sosial mereka salurkan untuk kepentingan kesejahteraan dan kegiatan pengelolaan lingkungan. Keterbatasan ketrampilan dan pengetahuan, pelaporan pendanaan ini belum sebaik Koperasi Depok. Meskipun demikian, masyarakat cukup antusias untuk berpartisipasi dalam pengelolaan lingkungan.

Dari pembentukan poklaksar wanita nelayan di pantai Baru, muncul ide arisanarisan bulanan, yang menjadi aksi kolektif ekonomi baru. Melalui pertemuan rutin bulanan, penyuluh menyampaikan beragam informasi yang dibutuhkan wanita nelayan termasuk dalam pengelolaan lingkungan. Keuntungan ganda diperoleh wanita nelayan. Di satu sisi, mereka mendapatkan modal tambahan bagi pengembangan usahanya, forum tersebut sebagai sarana silaturahmi sekaligus penggerak aspirasinya.

\section{KESIMPULAN DAN SARAN}

Penyadaran dan partisipasi stakeholder pariwisata termasuk wanita nelayan amat dibutuhkan dalam pengelolaan lingkungan yang berkelanjutan. Partisipasi ini mulai dari perencanaan, pelaksanaan, evaluasi hingga manfaat yang diterima wanita nelayan. Partisipasi yang semula bersifat simbolis di lokasi penelitian dapat dikembangkan dengan pendampingan penyuluh yang intensif terhadap kegiatan-kegiatan kelompok wanita nelayan mewujud menjadi partisipasi mandiri. Upaya menambah event-event wisata dan diversifikasi produk wisata, festival budaya lokal (upacara adat), pertunjukan kesenian (seni tari, theater dan seni musik) dan aspek kelestarian lingkungan (konservasi penyu), pembenahan fasilitas dan akses obyek wisata di antaranya taman bermain, aquarium biota laut, marine science tour, pencitraan baru semisal dengan Parangtritis dengan citra baru sebagai daerah wisata kuliner masakan laut yang murah dan higienis dan penataan lingkungan sekitar pantai, berpeluang meningkatkan pendapatan wanita nelayan dan wilayah.

\section{DAFTAR PUSTAKA}

Agustina, Ni Ketut Wiwik, 2012, Desa Budaya Kertalangu sebagai Usaha Daya Tank Wisata di Bali, Tesis, Universitas Udayana: unpublished.

AIDAB, 1991, Social Analysis and Community Participation: Guideline and Activity Cycle Checklist, AIDAB.

Anggraini, Oktiva, 2011, Pemberdayaan Kelompok Wanita Nelayan dalam Pengembangan Ecotourism (Ekowisata) Pantai Depok di Kabupaten Bantul, Prosiding Seminar Nasional, Kementrian Pendidikan Nasional, Kopertis Wilayah V Yogyakarta.

Anggraini, Oktiva, 2012 Pengembangan Model Pemberdayaan Wanita Nelayan dalam Penataan Wisata Kuliner yang Menunjang Program Minapolitan di Wilayah Pesisir Kabupaten Bantul, Laporan Penelitian Hibah Bersaing DIKTI, unpublished.

Arenas, MC, and A. Lentisco, 2011, Mainstreaming Gender into Project 
Cycle Management in Fishiries Sector: FAO, Bangkok 92.

Atmanto, 1995, Peran Pemerintah dan Partisipasi Masyarakat dalam Pembangunan Hutan Kota Studi Kasus di Kelurahan Krobokan Kecamatan Semarang Barat, Kotamadya Semarang, Tesis: Institut Pertanian Bogor.

Bengen, D. G, 2000. Pengenalan dan Pengelolaan Ekosistem dan Sumberdaya Pesisir, Makalah, IPBBogor.

Bengen, D. G, 2001, Sinopsis Ekosistem Sumberdaya Alam Pesisir dan Laut, Pusat Kajian Sumber Daya Pesisir dan Lautan, IPB, Bogor.

Bryant, Caroline dan White, Louise G, 1989, Manajemen Pembangunan untuk Negara Berkembang, Jakarta: LP3ES. 1982, Managing Development in the Third World, Colorado: Westview Press.

Chamala, S, 1995, Overview of Participative Action Approaches in Australian Land and Water Management in Chamal, S dan K. Keith (eds.) Participative Approaches for Land care, Brisbane Australian Academic Press.

Costanza, R. (ed)., 1991, Ecological Economics: The Science and Management of Sustainability, New York: Columbia University Press.

Fandeli, Chafid dan Muhammad Nurdin, 2005. Pengembangan Ekowisata Berbasis Konservasi di Taman Nasional, Penerbit Fakultas Kehutanan Universitas Gajah Mada dengan Pusat Studi Pariwisata Universitas Gajah Mada,
Yogyakarta dan Kantor Kementerian Lingkungan Hidup RI, Jakarta. 